\title{
FGF4 Gene Amplification
}

National Cancer Institute

\section{Source}

National Cancer Institute. FGF4 Gene Amplification. NCI Thesaurus. Code C41379.

A molecular genetic abnormality indicating the presence of multiple copies of the FGF4 gene. 